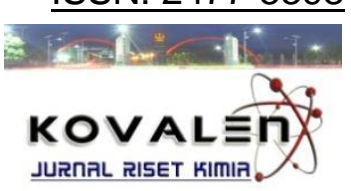

\title{
PEMANFAATAN KULIT JAGUNG (Zea mays) UNTUK PRODUKSI GLUKOSA MENGGUNAKAN KAPANG Trichoderma sp.
}

\section{[Utilization of Corn Husk (Zea mays) for Glucose Production Using Trichoderma sp.]}

\author{
Saiful Safari ${ }^{1}$, Syaiful Bahri $^{{ }^{\star}}$, Nurhaeni ${ }^{1}$ \\ 1) Jurusan Kimia FMIPA Universitas Tadulako, Palu \\ Jl. Soekarno Hatta, Kampus Bumi Tadulako Tondo Palu, Telp. 0451- 422611
}

Diterima 2 Desember 2016, Disetujui 9 Januari 2017

\begin{abstract}
This study uses corn husk for the production of glucose by fermentation with the fungus Trichoderma $\mathrm{sp}$. The aim is to determine the amount of Trichoderma sp. which is the best to produce the highest glucose with a variety of heavy fungus are 6,9 , and 12 grams in 25 grams of flour corn husk. Fermentation time variation 3,4 , and 5 weeks. Determination of the glucose level with DNS method using UV-Vis spectrophotometry. The study design using RAL factorial consisting of two factors, namely the weight of the fungus and fermentation time, each factor consists of 3 levels and is done in duplicate. The results showed that high glucose levels obtained in the addition of 12 grams of fungus and fermentation time 4 weeks with a glucose level of $21.72 \%$.
\end{abstract}

Keywords: Corn husk, Trichoderma weight, Time of fermentation, Glucose

\begin{abstract}
ABSTRAK
Penelitian ini menggunakan kulit jagung untuk produksi glukosa secara fermentasi dengan kapang Trichoderma sp. Tujuannya adalah untuk mengetahui jumlah Trichoderma $s p$. yang terbaik untuk menghasilkan glukosa tertinggi dengan berbagai variasi berat kapang yaitu 6, 9, dan 12 gram dalam 25 gram tepung kulit jagung. Variasi waktu fermentasi 3, 4, dan 5 minggu. Penentuan kadar glukosa dengan metode DNS menggunakan spektrofotometri UV-Vis. Rancangan penelitian menggunakan RAL pola faktorial yang terdiri atas dua faktor, yaitu berat jamur dan waktu fermentasi, masing-masing faktor terdiri atas 3 taraf dan dilakukan secara duplo. Hasil penelitian menunjukan bahwa kadar glukosa tertinggi diperoleh pada penambahan kapang 12 gram dan waktu fermentasi 4 minggu dengan kadar glukosa sebesar 21,72\%.
\end{abstract}

Kata kunci : Kulit jagung, Berat Trichoderma, Waktu fermentasi, Glukosa. 
LATAR BELAKANG

Beberapa negara saat ini menghadapi permasalahan serius berupa terbatasnya jumlah bahan bakar fosil, dilain pihak kebutuhan konsumen terus meningkat. Bahan bakar fosil yang digunakan secara terus menerus akan berujung pada peningkatan pemanasan global meningkat. Berdasarkan alas an tersebut sehingga mendorong upaya untuk mengembangkan bahan bakar terbarukan dan juga konservasi energi. Salah satu bentuk dari energi terbarukan adalah energi biomassa. Energi biomassa berasal dari bahan organik dan sangat beragam jenisnya. Tanaman dapat digunakan sebagai sumber energi biomassa, selain itu sumber lainnya dapat berasal dari limbah, baik limbah pertanian maupun limbah domestik (Gusmawarni, dkk, 2010).

Biomassa dari tanaman terdiri senyawa lignoselulosa dengan komponennya lignin, selulosa, dan hemiselulosa. Ketersediaan biomassa dari tanaman yang cukup melimpah, sehingga potensi sebagai salah satu sumber energi melalui proses konversi cukup besar. Proses konversi tersebut dapat dilakukan secara biologi, kimia, ataupun fisika. Salah satu proses konversi biomassa menjadi sumber bahan bakar yang cukup banyak diteliti, yaitu proses konversi lignoselulosa menjadi bioetanol. Bioetanol dimanfaatkan sebagai bahan subtitusi pada premium atau bensin yang digunakan sebagai bahan bakar kendaraan bermotor (Hermiati, dkk, 2010). Salah satu biomassa yang dapat diproses menjadi glukosa adalah tanaman jagung. Berdasarkan data Badan Pusat Statistik (BPS) Sulawesi Tengah, jumlah produksi jagung Sulawesi Tengah tahun 2013 sebesar 139.265 ton pipilan kering. Berdasarkan data tersebut, akan dapat menghasilkan limbah kulit jagung yang besar. Kandungan selulosa yang cukup banyak yaitu sekitar 36,81\% (Ningsih, 2012).

Selulosa merupakan senyawa polimer karbohidrat dari $\beta$-1,4-D-glikosida, sehingga jika rantai dari polimer tersebut dipotong-potong maka akan dihasilkan molekul glukosa. Rantai selulosa dapat diputus secara kimia maupun enzimatik atau biasa dikenal dengan istilah hidrolisis. Hidrólisis enzimatik pada senyawa selulosa umumnya menggunakan enzim selulase yang dihasilkan oleh mikroba. Apabila dibandingkan dengan hidrolisis kimiawi, hidrolisis secara enzimatik memerlukan waktu yang lebih lama jika dilakukan pada suhu kamar (Sukardati dkk, 2010).

Selulase secara komersial diproduksi menggunakan mikroba. Aspergillus niger, Trichoderma viride adalah contoh dua jenis kapang yang dapat menghasilkan selulas, sedangkan bakteri yang dapat memproduksi selulase, yaitu golongan Pseudomonas sp., Cellulomonas sp., dan Bacillus sp. Selain dari beberapa contoh tersebut, salah satu 
jenis mikroba yang potensial untuk dikembangkan dalam pembuatan enzim selulase adalah kelompok kapang Trichoderma, misalnya Trichoderma viride (Arnata, 2009).

Sarjono, dkk (2012), menyatakan bahwa kadar glukosa dari eceng gondok menggunakan Trichoderma viride pada suhu $35{ }^{\circ} \mathrm{C}$ dengan waktu fermentasi 96 jam, diperoleh dengan kadar glukosa tertinggi $1,386 \mathrm{mg} / \mathrm{L}$.

\section{METODE PENELITIAN}

\section{Bahan dan Peralatan}

Bahan-bahan yang digunakan adalah limbah kulit jagung, Trichoderma, aquadest, aluminium foil, kapas, dan pereaksi DNS.

Alat yang digunakan adalah neraca analitik, Labu ukur $25 \mathrm{~mL}$, ayakan 60 mesh, kertas saring, Spektrofotometer UV-Vis, autoclaf, batang pengaduk, Penangas air, Erlenmeyer, dan alat-alat gelas yang umum digunakan dalam laboratorium kimia.

\section{Prosedur Penelitian}

\section{Persiapan Tepung Kulit Jagung}

Perlakuan awal terhadap kulit jagung meliputi pencucian, pengeringan, dan pengayakan. Bahan pengotor pada kulit jagung seperti tanah, dan kotoran lain dihilangkan dengan cara dicuci. Hasil pencucian selanjutnya dikeringkan langsung di bawah sinar matahari. Kulit jagung kering kemudian digiling untuk mendapatkan ukuran kulit jagung yang lebih kecil. Kulit jagung yang sudah dihancurkan kemudian diayak menggunakan ayakan 60 mesh.

\section{Fermentasi}

Tepung kulit jagung ditimbang sebanyak $25 \mathrm{~g}$ kemudian dimasukan ke dalam Erlenmeyer, lalu ditambahkan 50 $\mathrm{mL}$ aquadest. Selanjutnya campuran tersebut disterilisasi pada suhu $121{ }^{\circ} \mathrm{C}$ selama 25 menit, lalu sampel didinginkan selama 30 menit. Percobaan dilakukan dengan variasi berat kapang trichoderma sebanyak 6, 9, dan 12 gram. Kemudian sampel didiamkan selama 3, 4, dan 5 minggu. Setelah itu, setiap sampel ditambahkan aquadest sebanyak $200 \mathrm{~mL}$, lalu disaring menggunakan kertas saring.

Penetapan Kadar Glukosa dengan Metode DNS (Modifikasi metode Daud, dkk, 2012)

\section{a. Pembuatan pereaksi DNS}

Pereaksi DNS di buat dengan $\begin{array}{llll}\text { melarutkan } \quad 0,265 & \mathrm{~g} \text { asam } & 3,5\end{array}$ dinitrosalisilat $0,495 \mathrm{~g} \mathrm{NaOH}$ ke dalam 35,4 $\mathrm{mL}$ air destilat, kemudian ditambahkan ke dalam larutan tersebut $7,65 \mathrm{~g}$ natrium kalium tatrat, $0,19 \mathrm{~mL}$ fenol (cairkan pada suhu $50^{\circ} \mathrm{C}$ ) dan $0,2075 \mathrm{~g}$ natrium metabisulfit, campur merata.

\section{b. Penyiapan Kurva Standar}

Kurva standar dibuat dengan mengukur absorbansi larutan glukosa standar pada panjang gelombang $550 \mathrm{~nm}$. Larutan glukosa standar dibuat dengan cara melarutkan 110 mg glukosa monohidrat dalam $100 \mathrm{~mL}$ aquadest, selanjutnya dari larutan tersebut 
diencerkan sehingga diperoleh larutan glukosa dengan konsentrasi ; 0, 10, 20, 30, 40, 50, 60, 70, 80, 90, 100 ppm. Masing-masing konsentrasi latutan tersebut diambil sebanyak $1 \mathrm{~mL}$ dan di masukkan ke dalam tabung reaksi, setelah itu ditambahkan $3 \mathrm{~mL}$ pereaksi DNS dan tabung dipanaskan pada air mendidih selama 5 menit dan didinginkan pada suhu ruang. Absorbansi masingmasing larutan diukur pada panjang gelombang maksimum $550 \mathrm{~nm}$.

\section{c. Penentuan Kadar Glukosa}

Sebanyak $1 \mathrm{~mL}$ larutan gula hasil hidrolisis dimasukkan ke dalam tabung reaksi dan ditambahkan dengan $3 \mathrm{~mL}$ pereaksi DNS, selanjutnya dipanaskan pada penangas air mendidih selama 5 menit kemudian didinginkan pada suhu ruang. Larutan dipindahkan ke dalam kuvet, absorbansi diukur pada panjang gelombang maksimum $550 \mathrm{~nm}$. Kadar gula ditentukan dengan menggunakan persamaan regresi.

\section{HASIL DAN PEMBAHASAN}

\section{Kadar Glukosa Hasil Hidrolisis dengan Pengaruh Berat Jamur}

Glukosa diperoleh melalui hidrolisis selulosa menggunakan enzim yang dihasilkan oleh jamur Trichoderma. Jamur Trichoderma merupakan salah satu mikroorganisme yang dapat memproduksi enzim selulase dan enzim tersebut berperan dalam hidrolisis selulosa dengan memutus ikatan $\beta$-1,4-D-glikosida yang selanjutnya menghasilkan glukosa.
Analisis glukosa hasil hidrolisis oleh enzim selulase dilakukan dengan menghitung kadar gula reduksi menggunakan metode DNS (Miller, dalam Amelia, 2012). 3,5-asam dinitrosalisilat (DNS) berupa senyawa aromatik akan bereaksi dengan gula reduksi pada sampel. Gugus aldehid bebas pada gula pereduksi akan membentuk kompleks 3amino-5 dinitro asam salisilat yang berwarna dan dapat dideteksi dengan spektrofotometer UV-Vis pada panjang gelombang $550 \mathrm{~nm}$.

Untuk mengetahui berat jamur terbaik terhadap serbuk kulit jagung yang menghasilkan kadar glukosa tertinggi pada proses hidrolisis selulosa dilakukan dengan mencampurkan jamur dengan substrat yang kemudian difermentasi selama 3, 4, dan 5 minggu. Berat jamur divariasikan mulai dari 6, 9, dan 12 gram sedangkan berat sampel yaitu 25 gram untuk masing-masing perlakuan. Hasil yang diperoleh (Gambar 1) menunjukkan bahwa kadar glukosa tertinggi $(21,72 \%)$ diperoleh pada berat jamur 12 gram dengan waktu fermentasi 4 minggu.

Grafik pada Gambar 1 menunjukan bahwa semakin banyak jamur yang digunakan maka semakin tinggi kadar glukosa yang dihasilkan dari proses hidrolisis selulosa pada serbuk kulit jagung. Poedjiadi (1994) telah mengemukakan bahwa konsentrasi enzim sangat mempengaruhi kecepatan reaksi suatu enzim dengan substratnya. Selain itu, dalam penelitian Yulianto dkk, (2009) 
menunjukan bahwa semakin besar rasio enzim-substrat, semakin meningkat kadar glukosanya. Hal ini terjadi karena semakin besar rasio enzim-substrat, maka tumbukan yang terjadi antar reaktan dengan enzim akan meningkat pula, sehingga interaksi sisi aktif enzim dengan substrat akan lebih sering terjadi.

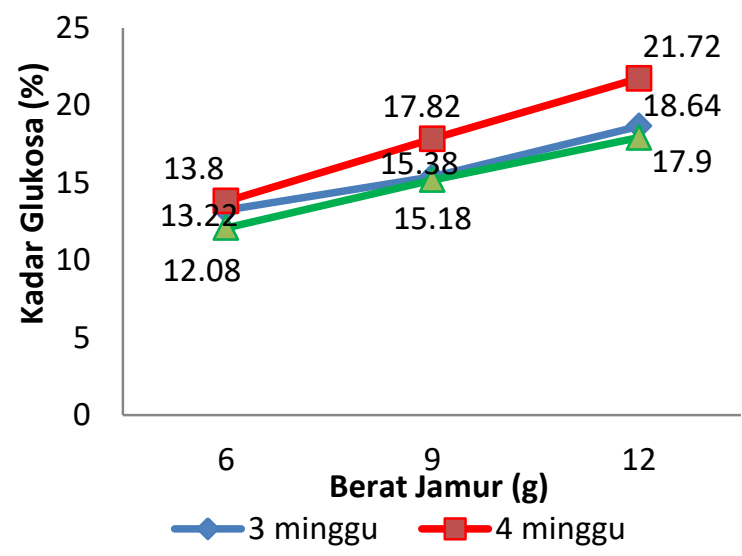

Gambar 1 Grafik hubungan antara berat jamur dengan kadar glukosa yang dihasilkan (\%)

Produk yang dihasilkan dari reaksi antara substrat dan enzim dipengaruhi oleh kondisi dari konsentrasi enzim maupun substrat. Pada keadaan konsentrasi enzim meningkat sedangkan konsentrasi substrat tetap atau jumlah molekul enzim lebih rendah dibandingkan jumlah molekul substrat yang akan dikatalisis, maka produk yang dihasilkan akan sebanding dengan jumlah substrat yang akan diubah oleh enzim menjadi produk. Bila jumlah enzim ditingkatkan makin banyak substrat yang akan diubah menjadi produk hingga suatu ketika jumlah enzim berlebih namun substrat habis. Akibatnya penambahan jumlah enzim tidak akan mengubah grafik kecepatan reaksi terhadap konsentrasi enzim (Adhiyanto, dkk dalam Amelia, 2012).

\section{Kadar Glukosa Hasil Hidrolisis dengan} Pengaruh Waktu Fermentasi

Untuk mengetahui pengaruh waktu fermentasi terhadap serbuk kulit jagung yang menghasilkan kadar glukosa tertinggi, diterapkan tiga tingkatan waktu fermentasi yaitu 3 minggu, 4 minggu, dan 5 minggu dengan berat jamur masingmasing 6 gram, 9 gram dan 12 gram. Hasil yang diperoleh (Gambar 2) menujukan kadar glukosa tertinggi $(21,72$ $\%)$ ditemukan pada waktu fermentasi 4 minggu dengan berat jamur 12 gram.

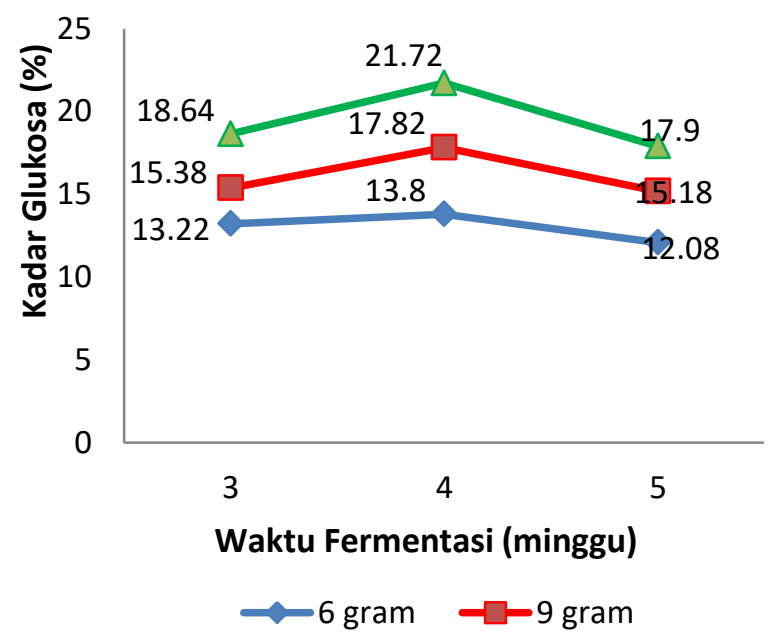

Gambar 2 Grafik hubungan antara waktu fermentasi dengan kadar glukosa yang dihasilkan (\%)

Grafik di atas menunjukan bahwa semakin lama waktu fermentasi semakin tinggi kadar glukosa, namun pada waktu tertentu mengalami penurunan. Hal ini sesuai dengan teori yang di kemukakan oleh Da Silva dalam Sari, dkk (2014) menyatakan bahwa sistem pemecahan 
selulosa menjadi glukosa terdiri dari tiga jenis selulase yaitu endo-beta-1,4glukanase, ekso-beta-1,4-glukanase, dan beta-glukosidase. Pada akhir hidrolisis enzimatis terjadi penurunan gula pereduksi total yang diduga terjadi karena tingginya gula pereduksi total yang terbentuk pada substrat telah terjadi feedback inhibition atau aktivitas enzim selulase terhambat dalam memproduksi gula pereduksi.

Khairunnisah, dkk (2013) juga melakukan penelitian tentang produksi bioetanol dari ampas sagu (Metroxylon sp) melalui proses pretreatment dan metode simultaneous saccharification fermentation (SSF). Proses sakarifikasi dilakukan dengan delapan variasi waktu yaitu $0,30,45,60,75,90,105$ dan 120 menit. Hasilnya menunjukan bahwa lama sakarifikasi yang optimum terdapat pada waktu 75 menit dengan konsentrasi glukosa tertinggi $882,50 \mu \mathrm{g} / \mathrm{mL}$. Pada waktu 0 hingga 75 menit jumlah substrat ampas sagu masih cukup banyak sehingga dengan semakin lamanya waktu hidrolisis, glukosa yang dihasilkan juga meningkat selain itu juga dapat disebabkan gula sebagai sumber nutrisi masih banyak tersedia sehingga memungkinkan peningkatan kerja enzim untuk terjadi peningkatan kadar glukosa, namun pada waktu 80 hingga 120 menit mengalami penurunan kadar glukosa dikarenakan semakin lamanya waktu hidrolisis jumlah substrat ampas sagu akan semakin berkurang karena telah banyak yang terhidrolisis sehingga glukosa yang dihasilkan cenderung menurun atau konstan.

Safaria dkk, (2013) menemukan hal yang sama dalam penelitiannya, peningkatan konsentrasi glukosa yang dihasilkan pada waktu hidrolisis 6 jam. Hasil tersebut menindikasikan terjadi interaksi tang tinggi antara enzim selulase dengan substratnya. Enzim selulase yang berinteraksi dengan selulosa selanjutnya membentuk kompleks enzim-substrat (ES) dan menghasilkan produk glukosa. Semakain lama interaksi yang terjadi antara enzim dengan substrat akan memaksimalkan reaksi yang terjadi sehingga glukosa yang dihasilkan akan memiliki konsentrasi yang lebih tinggi.

\section{KESIMPULAN}

Berdasarkan hasil penelitian yang diperoleh, maka dapat disimpulkan bahwa berat jamur 12 gram merupakan kondisi fermentasi terbaik untuk hidrolisis selulosa dengan kadar glukosa sebesar 21,72 \%. Waktu optimum untuk menghasilkan kadar glukosa tertinggi yaitu 4 minggu dengan kadar glukosa sebesar 21,72\%.

Perlu dilakukan penelitian lebih lanjut untuk mengetahui kondisi optimum dari penambahan berat jamur trichoderma untuk menghidrolisis selulosa pada serbuk kulit jagung.

\section{DAFTAR PUSTAKA}

Amelia A. 2012. Pengaruh Variasi Konsentrasi Enzim Dan Substrat Terhadap Sakarifikasi Limbah Pengolahan Kertas Menggunakan 
Enzim Selulase Dari Bacillus sp. BPPT CC RK2. [Skripsi]. Jakarta: Program Studi Farmasi Fakultas Kedokteran Dan IImu Kesehatan Universitas Islam Negeri Syarif Hidayatullah.

Arnata, I Wayan. 2009. Pengembangan Alternatif Teknologi Bioproses Pembuatan Bioetanol dari Ubi Kayu Menggunakan Trichoderma Viride, Aspergillus Niger dan Saccharomyces Cerevisiae. [Tesis]. Bogor: Sekolah Pascasarjana Institut Pertanian Bogor.

Daud. M., Safii, W., Syamsu, K., 2012. Biokonversi Bahan Berlignoselulosa Menjadi Bioetanol Menggunakan Aspergillus niger dan Sacchamromyces cereviciae. Jurnal Perennial, 8 (2) : 43-51.

Gusmawarni S.R., Budi, M.S.P., Sediawan, W.B., Hidayat, M. 2010. Pengaruh Perbandingan Berat Padatan dan Waktu Reaksi Terhadap Gula Pereduksi Terbentuk pada Hidrolisis Bonggol Pisang. Jurnal Teknik Kimia Indonesia, 9 (3): 77-82.

Hermiati, E., Mangunwidjaja, D., Sunarti, T.C., Suparno, O., Prasetya, B. 2010. Pemanfaatan Biomassa Lignoselulosa Ampas Tebu untuk Produksi Bioetanol. Jurnal Litbang Pertanian, 29 (4): 121-130

Khairunnisah, Salim, M., Mardiah, E., 2013. Produksi Bioetanl Dari Ampas Sagu (Metroxylon sp) Melalui Proses Pretreatment Dan Metoce Simultaneous Saccarification Fermentation (SSF). Jurnal Kimia Unand. 2(4):63-68.

Ningsih, E. R., 2012. Uji Kinerja Digester Pada Proses Pulping Kulit Jagung Dengan Variabel Suhu Dan Waktu Pemasakan. [Tugas Akhir]. Semarang: Program Studi Diploma
III Teknik Kimia Fakultas Teknik Universitas Diponegoro.

Poedjiadi A. 1994. Dasar-Dasar Biokimia. Jakarta: UI-Press.

Safaria S., Idiawati, N., dan Marlissa, T. 2013. Efektivitas Campuran Enzim Selulase Dari Aspergillus Niger Dan Trichoderma Reesei Dalam Menghidrolisis Substrat Sabut Kelama. JKK, 2 (1): 46-51.

Sari R. N., Utomo, B. S. B., Tambunan, A. H. 2014. Kondisi Optimum Produksi Bioetanol Dari Rumput Laut Coklat (Sargassum duplicatum) Menggunakan Trichoderma viride dan Pichia angophorae. JPB Perikanan, 9 (2): 121-132.

Sarjono P. R., Mulyani, N. S., dan Setyani, W. S. 2012. Kadar Glukosa Dari Hidrolisis Selulosa Pada Eceng Gondok Menggunakan Trichoderma viride Dengan Variasi Temperatur dan Waktu Fermentasi. Molekul, 7 (2): 163-171.

Sukardati S., Kholisoh, S.D., Prasetyo, H., Santoso, W, P., dan Mursini, T. 2010. Produksi Gula Reduksi Dari Sabut Kelapa Menggunakan Jamur Trichoderma reesei. Pengembangan Teknologi Kimia untuk Pengolahan Sumber Daya Alam Indonesia. Prosiding Seminar Nasional Teknik Kimia "Kejuangan"; Yogyakarta, 26 Januari 2010. Yogyakarta: UPN Veteran Yogyakarta. hlm D13-1 D13-7.

Yulianto M. E., Diyono, I., Hartati, I., Rustam S. N., dan Fiqih, P. J. 2009. Pengembangan Hidrolisis Enzimatis Biomassa Jerami Padi Untuk Produksi Bioetanol. Rekayasa Aplikasi Perancangan dan Industri. Simposium Nasional RAPI VIII; Surakarta, 17 Desember 2009. Surakarta: Fakultas Teknik UMS. hlm K-66 - K-73. 